University of Nebraska - Lincoln

DigitalCommons@University of Nebraska - Lincoln

2000

\title{
Viability of piping plover Charadrius melodus metapopulations
}

Jonathan $\mathrm{H}$. Plissner

USGS Forest and Rangeland Ecosystem Science Center

Susan M. Haig

USGS Forest and Rangeland Ecosystem Science Center, Susan_Haig@usgs.gov

Follow this and additional works at: https://digitalcommons.unl.edu/usgsstaffpub

Plissner, Jonathan H. and Haig, Susan M., "Viability of piping plover Charadrius melodus metapopulations" (2000). USGS Staff -- Published Research. 560.

https://digitalcommons.unl.edu/usgsstaffpub/560

This Article is brought to you for free and open access by the US Geological Survey at DigitalCommons@University of Nebraska - Lincoln. It has been accepted for inclusion in USGS Staff -- Published Research by an authorized administrator of DigitalCommons@University of Nebraska - Lincoln. 


\title{
Viability of piping plover Charadrius melodus metapopulations
}

\author{
Jonathan H. Plissner, Susan M. Haig* \\ USGS Forest and Rangeland Ecosystem Science Center, 3200 SW Jefferson Way, Corvallis, OR 97331, USA
}

Received 17 August 1998; received in revised form 24 November 1998; accepted 1 March 1999

\begin{abstract}
The metapopulation viability analysis package, vORTEX, was used to examine viability and recovery objectives for piping plovers Charadrius melodus, an endangered shorebird that breeds in three distinct regions of North America. Baseline models indicate that while Atlantic Coast populations, under current management practices, are at little risk of near-term extinction, Great Plains and Great Lakes populations require 36\% higher mean fecundity for a significant probability of persisting for the next 100 years. Metapopulation structure (i.e. the delineation of populations within the metapopulation) and interpopulation dispersal rates had varying effects on model results; however, spatially-structured metapopulations exhibited lower viability than that reported for single-population models. The models were most sensitive to variation in survivorship; hence, additional mortality data will improve their accuracy. With this information, such models become useful tools in identifying successful management objectives; and sensitivity analyses, even in the absence of some data, may indicate which options are likely to be most effective. Metapopulation viability models are best suited for developing conservation strategies for achieving recovery objectives based on maintaining an externally derived, target population size and structure. (C) 2000 Elsevier Science Ltd. All rights reserved.
\end{abstract}

Keywords: Metapopulation; Population viability analysis; Piping plover; Charadrius melodus; vorTEX

\section{Introduction}

One of the most challenging aspects of designing recovery plans for threatened and endangered species is determination of appropriate population recovery objectives. Under the US Endangered Species Act, these objectives must represent quantitative population goals for delisting [16 U.S.C. Section 1533(f) (B) (ii) (1988)]. Typically, species recovery goals have included attainment of specified population sizes and/or numbers of populations. Often, these goals have been based on historical records of population size and qualitatively-derived estimates of carrying capacities and habitat availability. As a result, the long-term viability of "recovered" populations is often in doubt (Tear et al., 1993).

Recent developments in population genetics and population modeling, however, have provided additional tools for assessing extinction risks of current and future populations. One approach that is now generally encouraged for recovery planning is the use of population viability analysis (PVA) to predict future population trends and indicate the roles of various demographic,

\footnotetext{
* Corresponding author. Tel.: +1-541-750-7482; fax:+1-541-758-

E-mail address: haigs@fsl.orst.edu (S.M. Haig).
} 7761 . genetic and environmental parameters in modifying those trends (National Research Council, 1995). From its conceptual inception as a tool for estimating minimum sizes of viable populations (Gilpin and Soule, 1986), PVA has become widely-used for modeling the demography of small populations (reviewed by Boyce, 1992). Furthermore, single-species, deterministic models have now given rise to commercially available, individual-based and matrix projection simulation models that incorporate spatial structure as well as elements of input parameter stochasticity. These spatially-explicit models (i.e. metapopulation viability analyses or mPVA) are particularly useful for consideration of species with fragmented distributions or otherwise distinctive subpopulations. Although PVA's in general have significantly advanced understanding of population processes, their practical implementation has been limited by lack of valid demographic and environmental data input values for most species (Boyce, 1992; Burgman et al., 1993; Caughley, 1994; Harcourt, 1995). In addition, modeling of metapopulations requires especially extensive data collection. Through sensitivity analyses of individual PVA parameters, however, one can determine how parameter uncertainty is likely to effect model outcomes and can therefore indicate which specific parameters may be of paramount importance 
for conservation research (Lacy, 1993). Nevertheless, caution is warranted in choosing appropriate species, with sufficient population data, for modeling efforts.

In this paper, we present efforts to model persistence of threatened and endangered populations of a migratory North American shorebird. Piping plovers (Charadrius melodus) are a wide-ranging species for which extensive demographic data have been collected throughout their range during the past 15 years (summarized in US Fish and Wildlife Service, 1988b, 1996; Haig, 1992). In addition, two complete international censuses of both breeding and wintering ranges have been conducted in the past decade (Haig and Plissner, 1993; Plissner and Haig, 1997), and annual monitoring efforts provide accurate breeding population estimates. Originally listed as threatened in 1978, the Committee on the Status of Endangered Wildlife in Canada declared the species endangered in 1985 (Haig, 1985). In 1986, piping plovers were federally listed under the US Endangered Species Act (US Fish and Wildlife Service, 1985).

In the US listing, three distinct breeding populations were identified (Fig. 1); Atlantic Coast and Northern Great Plains populations were listed as threatened and the Great Lakes birds were considered endangered. Historically, piping plovers were distributed throughout the Great Lakes; however, breeding is currently restricted to a remnant population in Michigan that may maintain low levels of exchange with the Great Plains populations (Haig and Oring, 1988a). Although winter distributions overlap, there is currently no evidence of mixing between the three breeding populations (Haig and Oring, 1988a,b). In 1988, two recovery plans, one for the US Atlantic Coast (US Fish and Wildlife Service, 1988a) and a second for the Great Lakes and Northern Great Plains (US Fish and Wildlife Service, 1988b) were produced by separate recovery teams. The following year, a Canadian Recovery plan for the species established recovery teams for Atlantic and Prairie Canada (Canadian Wildlife Service, 1989), and the four teams have collaborated extensively on overall recovery efforts for the species during the past 15 years.

Breeding habitat, dispersal patterns, habitat distribution, and threats to the species vary extensively between the three populations, suggesting different population dynamics and clearly requiring multiple approaches toward recovery (Haig, 1992). Already, two single-population simulation models, one by Melvin and Gibbs (1994) for the Atlantic Coast and another by Ryan et al. (1993) for the Great Plains, have been developed to better quantify population recovery objectives; however, neither addressed the spatial distribution within their "populations" and how that distribution will alter model results (Wu et al., 1993). Consideration of the spatial structure of populations may be especially pertinent for birds in the Great Plains, which are characterized by heterogeneous breeding habitat types and large distances between breeding sites.

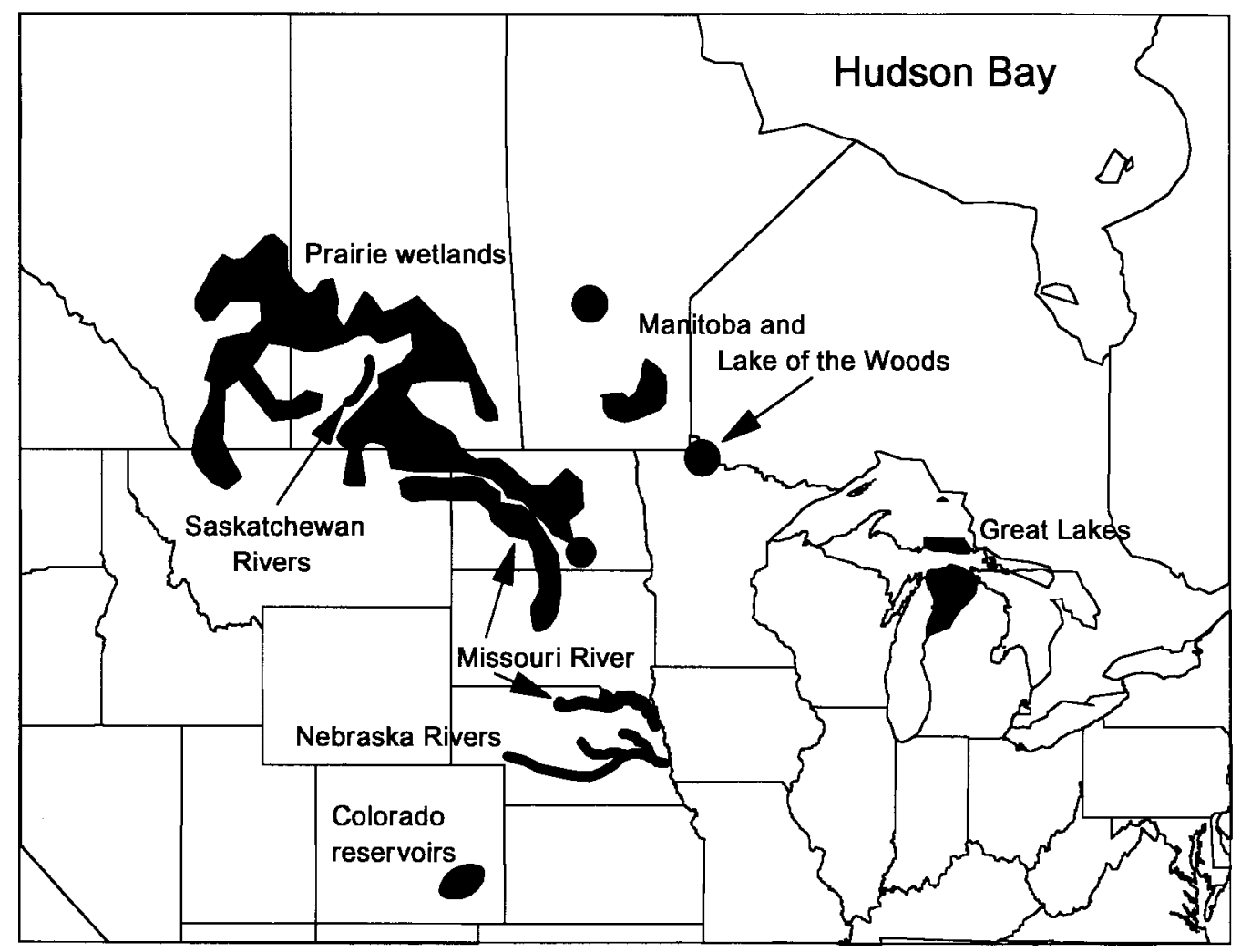

Fig. 1. 1996 piping plover breeding distributions and baseline metapopulation structure. 
Thus, our goal was to take a metapopulation approach to assess species status across the three populations and to draw general conclusions regarding the use of these models in setting recovery objectives. We used the stochastic simulation package, VORTEx, Version 7 (Lacy et al., 1995) to examine population trends. We compare our results to the single-population models and more extensively consider the roles of mortality, fecundity, and interpopulation movements as determinants of population trends. We also test sensitivity of models to varying input values.

\section{Methods}

\subsection{Metapopulation structure}

For conservation considerations, a metapopulation may be defined as an assemblage of spatially distinct but interconnected populations, among which at least some are susceptible to extinction and recolonization (McCullough, 1996). We use the term population to represent individual model units that are not further subdivided. These may be specific regions within a metapopulation (e.g. Missouri Coteau or New England populations) or, in the case of single-population models, may refer to larger-scale groupings (e.g. Atlantic Coast or Great Lakes/Great Plains). Because there is no evidence for mixing between Atlantic and inland breeding populations and because subspecies status associated with the two regions is still subject to debate (Haig, 1992; US Fish and Wildlife Service, 1996), we conducted separate simulations of the Atlantic Coast and Great Lakes/Great Plains metapopulations.

We first developed baseline models from available demographic data. From these initial models, we subsequently considered their responsiveness to variability in the input parameters, in order to examine how uncertainty in the baseline values, changes in these values over time, or management efforts might alter resulting viability projections. The baseline models reduced each metapopulation into several component populations (Fig. 1, Tables 1 and 2). The Atlantic coast structure was based upon the four recovery units identified in the revised Atlantic Coast Piping Plover Recovery Plan (US Fish and Wildlife Service, 1996), which are defined by political boundaries. Alternatively, the Great Lakes/Great Plains metapopulation, is composed of five geographically distinct regions, that transcend political boundaries.

\subsection{Model assumptions and input parameters}

Baseline demographic input values were derived from a compilation of all known piping plover data reported in published papers, agency reports, annual summary reports and communications, theses, dissertations, and all band recoveries since 1955 (see Acknowledgements). We simplified our models by omitting consideration of density-dependent reproduction and mortality, inbreeding depression, and catastrophic events; parameters for which there is either no supportive evidence for effects on piping plover populations or for which effects are already incorporated into the input data values. We furthermore made the simplifying assumptions of equal dispersal of sexes and age classes, equal sex ratios, and a stable initial age distribution. Initial population sizes were based on numbers obtained during the 1996 International Piping Plover Census, the most thorough census effort for a wide-ranging endangered bird (Plissner and Haig, submitted). In 1996, census results indicated a total of approximately 5900 breeding piping plovers, including 2540 along the Atlantic Coast, 48 in the Great Lakes, and 3284 in the Great Plains and Canadian Prairie. Carrying capacity $(K)$ estimates were derived from specific regional recovery objectives as stated in the respective recovery plans (US Fish and Wildlife Service, 1988b, 1996). Models were run through 500 iterations, simulating 100 years each.

\subsubsection{Fecundity and mortality}

Reproductive success was operationally defined as the number of fledged young per pair and was derived for each population from annual productivity estimates (Atlantic Coast, 1991-1995, Table 1) and various local studies (Great Lakes and Great Plains, Table 2). Mean overall baseline productivity for the Atlantic metapopulation was 1.37 fledglings per pair and 1.25 fledglings per pair for Great Lakes and Great Plains piping plovers. Based on similarity of habitat types, environmental variance in reproductive success on the Great Lakes and Atlantic coast was based on a coefficient of variation (C.V.) of 0.4, used for earlier Atlantic Coast models (Melvin and Gibbs, 1994). Slightly higher variance, using C.V. of 0.5 was used for the Great Plains populations, where habitats are more variable.

Baseline mortality rates for adults followed those used by Ryan et al. (1993) and Melvin and Gibbs (1994) and were based respectively upon studies at one North Dakota location (Root et al., 1992) and on outer Cape Cod, MA (L. MacIvor, C. Griffin and S. Melvin, unpublished data). First-year survivorship values for the species have only been derived from the Massachusetts study. We computed a baseline mortality value for firstyear mid-continent populations from the ratio of adult to juvenile (first-year) survivorship reported from Cape Cod. This value is lower than Ryan et al.'s (1993) minimum estimate for the US Great Plains, derived from studies of other plover species. In addition, environmental variance in mortality was determined by a constant coefficient of variation of 0.2 , as determined for the Atlantic Coast population (Melvin and Gibbs, 1994). 
Table 1

Baseline metapopulation structure of Atlantic Coast piping plovers ${ }^{\mathrm{a}}$

\begin{tabular}{|c|c|c|c|c|c|}
\hline Population & Description & $K$ & $\begin{array}{l}\text { Initial } \\
\text { population size }\end{array}$ & $\begin{array}{l}\text { 1st year/adult } \\
\text { mortality }\end{array}$ & $\begin{array}{l}\text { Mean no. fledged } \\
\text { per pair }\end{array}$ \\
\hline Atlantic metapopulation & & 4000 & 2540 & $51.64 / 26.13$ & 1.37 \\
\hline 1. Atlantic Canada & $\begin{array}{l}\text { Newfoundland, Nova Scotia, } \\
\text { Prince Edward Island, } \\
\text { New Brunswick, Quebec, } \\
\text { St. Pierre and Miquelon (France) }\end{array}$ & 800 & 384 & $51.64 / 26.13$ & 1.28 \\
\hline 2. New England & $\begin{array}{l}\text { Maine, Massachusetts, } \\
\text { Rhode Island, Connecticut }\end{array}$ & 1250 & 1118 & $51.64 / 26.13$ & 1.75 \\
\hline 3. Mid-Atlantic & New York, New Jersey & 1150 & 718 & $51.64 / 26.13$ & 1.07 \\
\hline 4. Southern Region & $\begin{array}{l}\text { Delaware, Maryland, Virginia, } \\
\text { North Carolina, South Carolina }\end{array}$ & 800 & 320 & $51.64 / 26.13$ & 0.98 \\
\hline
\end{tabular}

${ }^{a}$ Sources: personal communications/unpublished annual reports of authors listed in Acknowledgements.

Table 2

Baseline metapopulation structure of Great Lakes/Northern Great Plains piping plovers ${ }^{\mathrm{a}}$

\begin{tabular}{|c|c|c|c|c|c|}
\hline Population & Description & $K$ & $\begin{array}{l}\text { Initial population } \\
\text { size }\end{array}$ & $\begin{array}{l}1 \text { st year/adult } \\
\text { mortality }\end{array}$ & $\begin{array}{l}\text { Mean no. } \\
\text { fledged per pair }\end{array}$ \\
\hline Metapopulation & & 5891 & 3332 & $56.8 / 34.0$ & 1.25 \\
\hline 1. Great Lakes & L. Superior, L. Michigan, L. Erie & 300 & 48 & $56.8 / 34.0$ & 1.46 \\
\hline $\begin{array}{l}\text { 2. Manitoba and } \\
\text { Lake of the Woods }\end{array}$ & Manitoba and Lake of the Woods & 250 & 73 & $56.8 / 34.0$ & 0.53 \\
\hline 3. Northern Prairie & $\begin{array}{l}\text { Alberta, Saskatchewan Montana, and Dakotas, } \\
\mathrm{N} \text { and S Saskatchewan Rivers, } \\
\text { include. L. Diefenbaker }\end{array}$ & 4700 & 2786 & $56.8 / 34.0$ & 1.28 \\
\hline 4. Nebraska Rivers & $\begin{array}{l}\text { Platte, Loup, Elkhorn, Niobrara, } \\
\text { and Missouri below Fort Randall Dam }\end{array}$ & 500 & 412 & $56.8 / 34.0$ & 1.11 \\
\hline 5. Colorado & Reservoirs in SE quadrant of state & 40 & 13 & $56.8 / 34.0$ & 0.73 \\
\hline
\end{tabular}

a Sources: personal communications/unpublished annual reports of authors listed in Acknowledgements.

\subsubsection{Dispersal}

Although nearly all Atlantic and many inland breeding populations have been extensively monitored for at least 10 years, only two of over 3700 individuals banded on breeding grounds since 1980 have been identified as breeders in other populations. Both individuals, resighted in New Jersey, were among 121 birds originally captured and banded in Maryland (Loegering, 1992). We therefore used a baseline dispersal rate of 0.01 birds per year between adjacent populations, except between rivers and adjoining wetlands, for which a rate of 0.02 birds per year could account for increased mixing associated with climatic fluctuations and closer proximity. Although local philopatry rates are lower for juveniles (Wilcox, 1959; Haig and Oring, 1988a; Root et al., 1992), there are insufficient data to assess age-specific patterns at longer distances; thus, we assumed equal probabilities of interpopulation movements by juveniles and adults. Furthermore, for purposes of the model, we assumed that these movements did not entail additional mortality risks to dispersers.

\subsection{Sensitivity analyses and model comparisons}

We examined the sensitivity of the models to variation in input parameter values in order to (1) assess the effect of inaccurate input values on model results and (2) indicate which parameters may be of particular significance to researchers and managers for monitoring and enhancing population viability. Sensitivity analyses for different rates of juvenile mortality and interpopulation movements were necessary because of insufficient demographic data available for accurate estimation. Sensitivity was determined by incrementally changing single parameter values for all populations within the metapopulation.

To determine the significance of metapopulation structure on viability, we also considered a Great Lakes/ Great Plains metapopulation that was further subdivided by physiogeographic habitat characteristics, to reflect known differences in breeding characteristics at these sites. This model separated out birds breeding on alkali and freshwater lake shorelines from those nesting 
along major rivers and reservoir systems. We also compared results of our metapopulation models to singlepopulation (panmictic) models for Atlantic Coast (Melvin and Gibbs, 1994) and Great Plains (Ryan et al., 1993) populations. We used equivalent input values to those required for population stability with the singlepopulation models: Reproductive success $(\mathrm{RS})=1.25$ fledged/pair for Atlantic populations and $\mathrm{RS}=1.13$ fledged/pair for Great Plains birds. We further examined whether such demographic values predicted stability in panmictic and metapopulation models, given 1996 population sizes.

Finally, we compared predictions of the model with population trends for the Atlantic Coast metapopulation between 1991 and 1996, using results of the International Piping Plover Census (Haig and Plissner, 1993; Plissner and Haig, 1997). We then determined an appropriate survivorship rate that gave the best fit of the model to the census numbers for the entire metapopulation. We subsequently assessed the predictions of the fitted model against trends observed for the component Atlantic populations.

\section{Results}

\subsection{Baseline models}

In the Great Lakes and Great Plains, the five piping plover populations are unlikely to persist, given current reproductive rates and estimates of survivorship and dispersal (Table 3). Alternatively, with input values reflecting mean reported fecundity throughout the region and survivorship estimates from one site, all Atlantic Coast populations of piping plovers have greater than $95 \%$ likelihood of persistence for 100 years (Table 4). Only New England numbers approached population saturation levels $(K)$, while Mid-Atlantic (New York/New Jersey) and particularly Southern Region populations dropped substantially from current numbers, resulting in an overall $15 \%$ decrease in size of the metapopulation from its current status.

\subsection{Reproductive rates}

With a mean reproductive rate of 1.25 fledglings per pair, the Atlantic Coast metapopulation and all component populations persisted through the simulation period. However, while three populations demonstrated relatively stable numbers, this fecundity value is lower than current rates in New England (MacIvor, 1990), and population numbers decreased by $40 \%$ by the end of the simulation. No extinctions occurred in any of the four populations during the simulation period.

Retaining all other parameters at baseline levels, a mean reproductive success of 1.7 fledglings per pair per year was needed to exceed a $95 \%$ probability of persistence for the Great Lakes/Great Plains metapopulation over 100 years (Fig. 2). This represents an increase of $35 \%$ over current estimated reproductive rates. Even so, persistence does not equate with a stable population, and at such high fecundity rates, the metapopulation size still declined by two-thirds. A mean productivity of 2.0 fledglings per pair was required to maintain the current population size (Table 5). Even then, however, some populations, particularly the Great Lakes, are unlikely to persist under this scenario $(P<30 \%)$.

Recognizing that we used high estimates of reproductive variance, we also ran models with standard deviations half those of the baseline model. Persistence increased somewhat, with productivity of roughly 1.55 fledged per pair required for Great Lakes/Great Plains metapopulation persistence over 100 years. For Atlantic populations, a $50 \%$ reduction in standard deviations resulted in a $13 \%$ increase in overall metapopulation numbers after 100 years.

\subsection{Survivorship}

The Great Lakes/Great Plains model was highly sensitive to survivorship, attaining nearly $100 \%$ probability of persistence of the metapopulation with less than a $10 \%$ increase over baseline rates. Persistence again did not equate with stable population sizes; however, the

Table 3

Results of Great Lakes/Great Plains/Prairie baseline model

\begin{tabular}{|c|c|c|c|c|c|c|}
\hline & \multicolumn{6}{|l|}{ Population } \\
\hline & Metapopulation & Great Lakes & $\begin{array}{l}\text { Manitoba and } \\
\text { Lake of the Woods }\end{array}$ & $\begin{array}{l}\text { N. Missouri River } \\
\text { and Coteau }\end{array}$ & $\begin{array}{l}\text { Nebraska } \\
\text { rivers }\end{array}$ & Colorado \\
\hline \multicolumn{7}{|l|}{ Baseline model } \\
\hline Probability of survival for 100 years (SE) & $0.002(0.002)$ & 0 & 0 & $0.002(0.002)$ & 0 & 0 \\
\hline Mean final population size ${ }^{a}(\mathrm{SE})$ & $18(0)$ & 0 & 0 & $18(0)$ & 0 & 0 \\
\hline Mean years to first extinction ${ }^{b}$ (SE) & $55.39(0.56)$ & $30.64(0.75)$ & $32.27(0.44)$ & $51.15(0.56)$ & $46.71(0.52)$ & $22.05(0.39$ \\
\hline Population growth rate $(r)$ & -0.136 & -0.103 & -0.115 & -0.142 & -0.113 & -0.091 \\
\hline
\end{tabular}

a For populations persisting 100 years.

b For populations going extinct. 
Table 4

Results of Atlantic Coast piping plover metapopulation models

\begin{tabular}{|c|c|c|c|c|c|}
\hline & \multicolumn{5}{|l|}{ Population } \\
\hline & Atlantic metapopulation & Atlantic Canada & New England & Mid-Atlantic & Southern Region \\
\hline \multicolumn{6}{|l|}{ Baseline model } \\
\hline Probability of survival for 100 years & 1.000 & 1.000 & 1.000 & 1.000 & 0.996 \\
\hline Mean final extant population size \pm SE) & $2172 \pm 6.19$ & $579 \pm 8.28$ & $1159 \pm 7.81$ & $367 \pm 9.11$ & $68 \pm 2.25$ \\
\hline Population growth rate $(r)$ & 0.073 & 0.032 & 0.126 & -0.006 & -0.015 \\
\hline \multicolumn{6}{|l|}{ Fecundity $=1.25$ fledged $/$ year } \\
\hline Probability of survival for 100 years & 1.000 & 1.000 & 1.000 & 1.000 & 1.000 \\
\hline Mean final extant population size $( \pm$ SE) & $2571 \pm 29.07$ & $547 \pm 8.85$ & $751 \pm 14.68$ & $741 \pm 13.89$ & $532 \pm 9.55$ \\
\hline Population growth rate $(r)$ & 0.023 & 0.022 & 0.010 & 0.014 & 0.021 \\
\hline
\end{tabular}

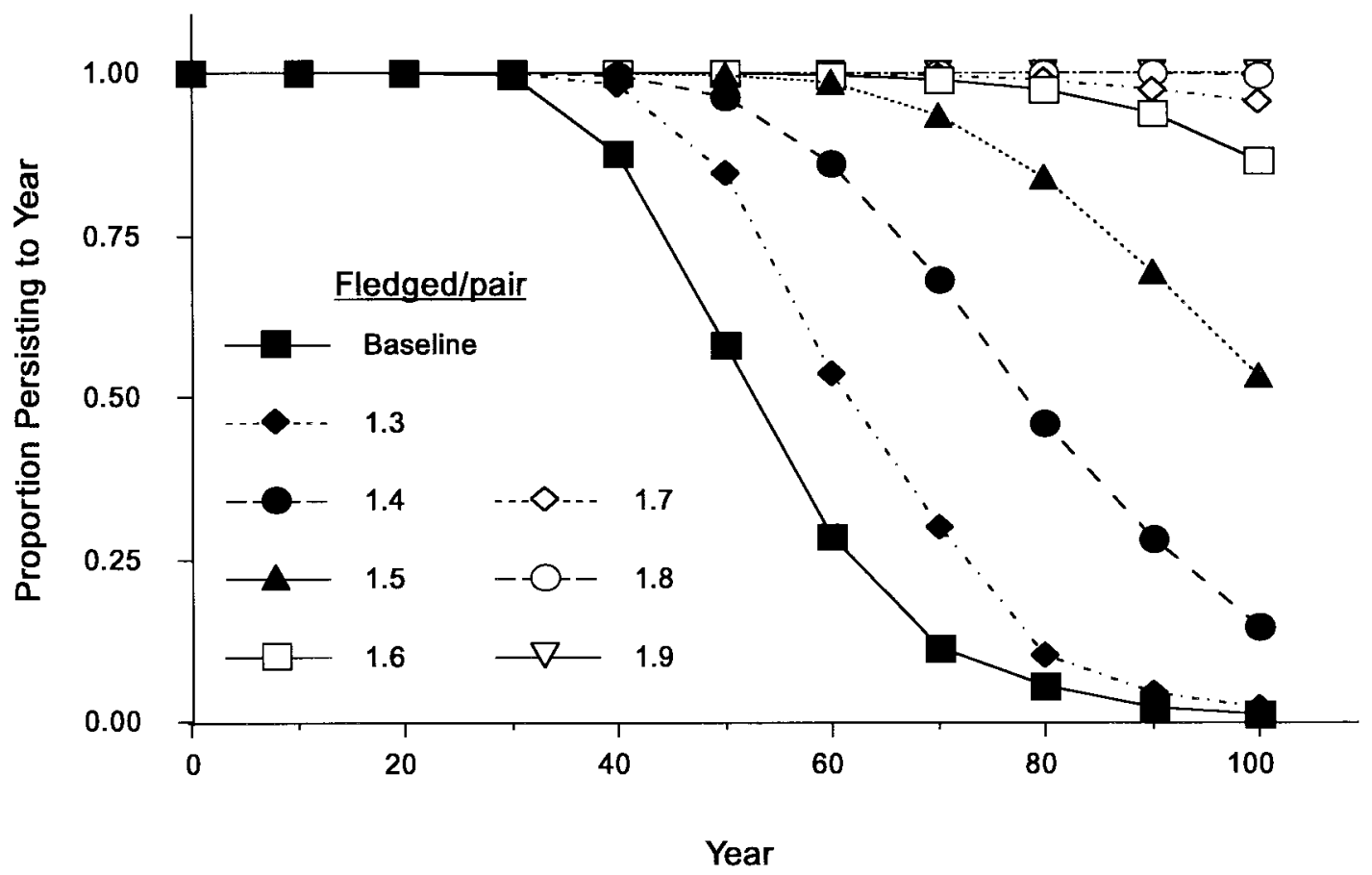

Fig. 2. Probability of Great Lakes/Great Plains piping plover metapopulation persistence relative to mean number of offspring fledged per pair.

Table 5

Persistence and size of Great Lakes/Great Plains populations at reproductive success $(\mathrm{RS})=1.7$ and $\mathrm{RS}=2.0$

\begin{tabular}{|c|c|c|c|c|}
\hline \multirow[b]{2}{*}{ Population } & \multicolumn{2}{|l|}{$\mathrm{RS}=1.7$ fledged per pair } & \multicolumn{2}{|l|}{$\mathrm{RS}=2.0$ fledged per pair } \\
\hline & $\begin{array}{l}\text { Probability of survival for } \\
100 \text { years (SE) }\end{array}$ & $\begin{array}{l}\text { Mean final } \\
\text { population size }(\mathrm{SE})\end{array}$ & $\begin{array}{l}\text { Probability of survival } \\
\text { for } 100 \text { years (SE) }\end{array}$ & $\begin{array}{l}\text { Mean final } \\
\text { population size }{ }^{\mathrm{a}}(\mathrm{SE})\end{array}$ \\
\hline Metapopulation & $0.958(0.009)$ & $694.84(40.35)$ & $0.998(0.002)$ & $2398.77(72.91)$ \\
\hline Great Lakes & $0.328(0.021)$ & 84.73 (7.02) & $0.798(0.018)$ & $181.01(5.00)$ \\
\hline Manitoba and Lake of the Woods & $0.870(0.015)$ & $104.08(3.95)$ & $0.996(0.003)$ & $185.10(3.26)$ \\
\hline Missouri River/Coteau & $0.904(0.013)$ & $417.23(34.69)$ & $0.998(0.002)$ & $1671.19(66.91)$ \\
\hline Platte River, NE & $0.884(0.014)$ & $171.88(7.32)$ & $0.998(0.002)$ & $366.43(6.60)$ \\
\hline Colorado & $0.758(0.019)$ & $23.44(0.64)$ & $0.982(0.006)$ & $32.06(0.44)$ \\
\hline
\end{tabular}

\footnotetext{
${ }^{\text {a }}$ For populations persisting 100 years.
} 
Great Lakes/Great Plains metapopulation quickly approached carrying capacity with $20 \%$ higher survivorship. This effect was principally a result of the model's response to adult survivorship, as the probability of population persistence after 100 years was twice as high following an increase in adult survivorship as it was resulting from a corresponding increase in juvenile survival rates (Fig. 3).

\subsection{Metapopulation connectivity and structure}

The degree of population connectivity within the metapopulation model did influence overall persistence; however, the direction of the effects differed between the two metapopulations. For the Atlantic breeding populations, increased connectivity of the populations resulted in higher total numbers of piping plovers and increasing population sizes for all except New England populations. For the Great Lakes/Great Plains metapopulation, however, greater interpopulation dispersal rates resulted in decreased viability of the metapopulation (Table 6). With no dispersal between populations, the probability of persistence of the metapopulation for 100 years was an order of magnitude higher than with baseline dispersal rates, while persistence probabilities remained extremely low at higher dispersal rates. Metapopulation viability was closely tied to population trends in the largest component population, the Missouri Coteau region. Here, persistence probabilities were negligible in nearly all cases with even low dispersal probabilities, and persistence times declined as dispersal rates increased. Conversely, persistence times for smaller populations such as the Great Lakes increased with greater dispersal rates.

Using baseline demographic values, variation in metapopulation structure significantly affected Atlantic Coast model results. The total number of Atlantic plovers, assuming a single panmictic population, increased

Table 6

Connectivity and persistence of Atlantic and Great Lakes/Great Plains metapopulations

\begin{tabular}{|c|c|c|c|c|c|}
\hline \multirow[b]{2}{*}{$\begin{array}{l}\text { Interpopulation } \\
\text { dispersal rates }\end{array}$} & \multicolumn{2}{|c|}{ Atlantic } & \multicolumn{3}{|c|}{ Great Lakes/Great Plains } \\
\hline & $P_{s}{ }^{\mathrm{a}}$ & $\begin{array}{l}N_{100}{ }^{\mathrm{b}} \\
(n)\end{array}$ & $\begin{array}{l}P_{s}^{\mathrm{a}} \\
(\mathrm{SE})\end{array}$ & $\begin{array}{l}N_{100}{ }^{\mathrm{b}} \\
(n)\end{array}$ & $\begin{array}{l}T_{\text {ext1 }}{ }^{\mathrm{c}} \\
(\mathrm{SE})\end{array}$ \\
\hline No dispersal & 1.000 & $\begin{array}{l}1676 \\
(16)\end{array}$ & $\begin{array}{c}0.186 \\
(0.017)\end{array}$ & $\begin{array}{l}70.94 \\
(93)\end{array}$ & $\begin{array}{l}69.73 \\
(0.82)\end{array}$ \\
\hline Baseline rates & 1.000 & $\begin{array}{l}2172 \\
(16)\end{array}$ & $\begin{array}{c}0.014 \\
(0.005)\end{array}$ & $\begin{array}{l}32 \\
(7)\end{array}$ & $\begin{array}{l}54.17 \\
(0.58)\end{array}$ \\
\hline $2 \times$ Baseline & 1.000 & $\begin{array}{l}2483 \\
(17)\end{array}$ & $\begin{array}{c}0.016 \\
(0.006)\end{array}$ & $\begin{array}{l}25.88 \\
(8)\end{array}$ & $\begin{array}{l}46.62 \\
(0.54)\end{array}$ \\
\hline $10 \times$ Baseline & 1.000 & $\begin{array}{l}3209 \\
(22)\end{array}$ & $\begin{array}{c}0.010 \\
(0.004)\end{array}$ & $\begin{array}{c}13.80 \\
(5)\end{array}$ & $\begin{array}{l}37.68 \\
(0.57)\end{array}$ \\
\hline
\end{tabular}

a Probability of survival for 100 years (SE).

b Mean final population size of $n$ populations (out of 500 runs) persisting 100 years.

c Mean time to first extinction for populations going extinct at least once during runs.

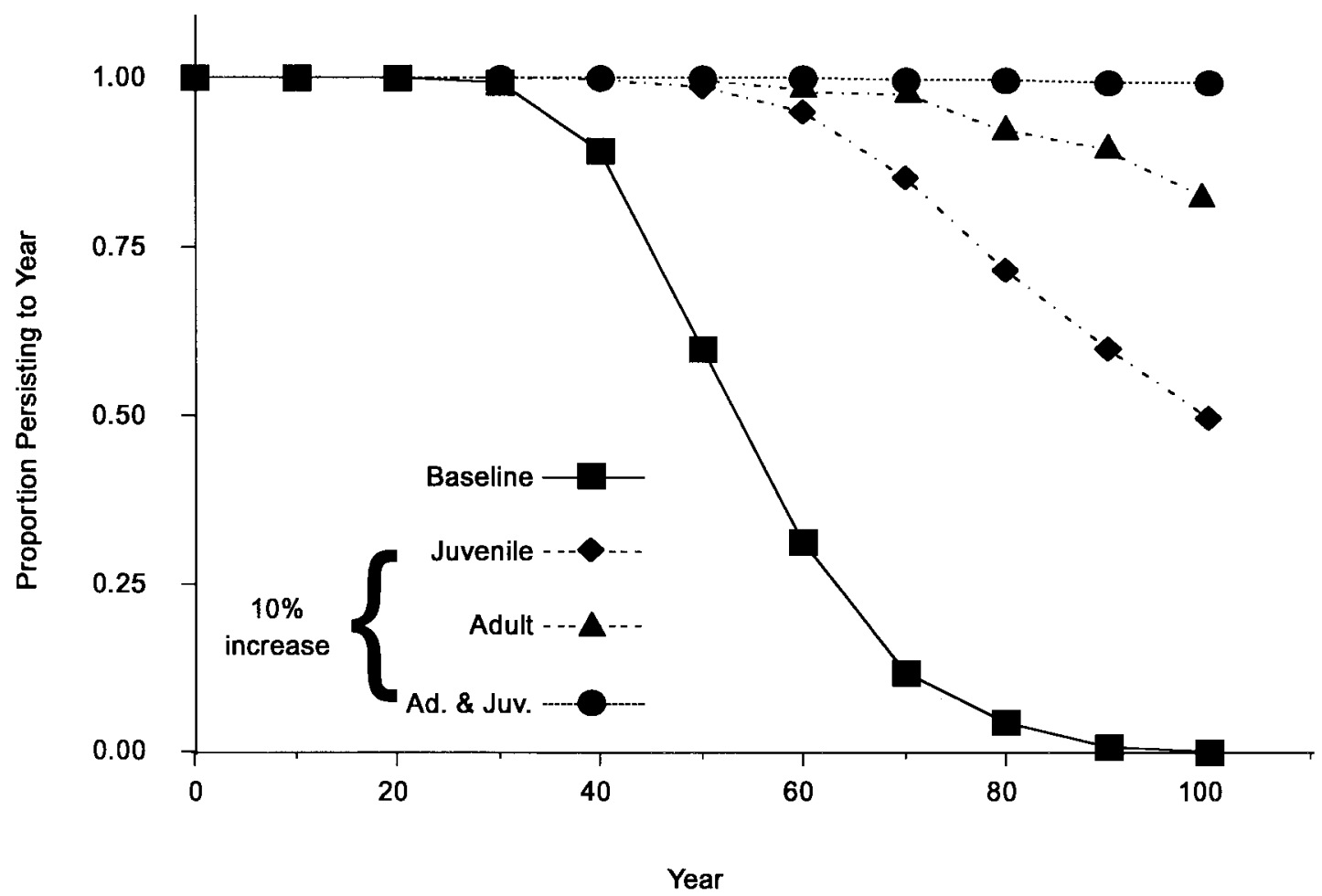

Fig. 3. Probability of Great Lakes/Great Plains piping plover metapopulation persistence as an effect of a $10 \%$ increase over baseline adults and/or juvenile survivorship. 
rapidly and reached an equilibrium size $50 \%$ higher than the baseline metapopulation model. Alternatively, population structure had little effect on persistence probabilities for Great Lakes/Great Plains piping plovers, as neither of the metapopulation models differed substantially from a panmictic, single-population model.

Overall, the models indicated that under current demographic conditions, Atlantic Coast populations are substantially more viable than are those of the Great Lakes and Great Plains. Furthermore, population structure may have varying effects upon persistence and viability, depending upon demographic parameters.

\subsection{Comparison with census results}

Using baseline demographic values and 1991 population estimates, the model predicted that the Atlantic Coast breeding population would increase from 1979 to 2372 individuals $(20 \%, \mathrm{SD}=317.5)$ over a 5 -year period. In 1996, 2581 adults (a 30.4\% increase) were reported for the entire Atlantic population (Haig and Plissner, 1997), significantly more than predicted by the model $\left(t=14.72, \mathrm{df}=499, p_{\text {two-tailed }}<0.001\right)$. The model was adjusted to match the census results by increasing juvenile survivorship by $6 \%$, or $70 \%$ of adult survivorship. Although predicted and observed 1996 metapopulation sizes were equalized, the model then significantly (all $p<0.01$ ) overestimated population sizes for Atlantic Canada (615 adults predicted, 428 observed) and the Southern Region (367 predicted, 327 observed), while underestimating increases in New England (985 predicted, 1124 observed) and the Mid-Atlantic coast (614 predicted, 702 observed).

\section{Discussion}

\subsection{Model comparisons}

Comparing our metapopulation models to singlepopulation models of Melvin and Gibbs (1994) and Ryan et al. (1993), we found that subdividing the piping plover breeding range resulted in lower viability than that of panmictic, single-population models. This likely results from two factors: increased risk of local extinctions in smaller populations and decreased viability of larger populations through source/sink dynamics. This does not imply that maintenance of small populations is necessarily detrimental to overall species survivorship. These populations tend to be peripheral to the center of a species' range and may be valuable for both their genetic distinctiveness (Lesica and Allendorf, 1995) and unique persistence capabilities (Lomolino and Channell, 1995). As is perhaps the case in piping plovers, small populations may also serve as corridors for gene flow between larger populations.
Ryan et al. (1993) suggested that their model best reflected population trends between 1986 and 1990 with a juvenile survivorship rate of 0.6 , or $90 \%$ that of adults. This represents a $40 \%$ increase over our baseline values and is far higher than any study of piping plovers has suggested. Furthermore, despite evidence for extensive juvenile dispersal (Haig and Oring, 1988a), such high survivorship would almost certainly be, but is not, reflected in band recovery data. At such a rate, Ryan et al. (1993) concluded that a mean fecundity of 1.13 fledgling per pair per year was necessary to maintain a stable population size for the Great Plains. Using our model and current population estimates, we were unable to replicate the results, noting a substantial decline in population size, following both panmictic and metapopulation model structures under such conditions.

Melvin and Gibbs (1994) estimated that a mean fecundity of 1.245 fledglings per pair per year was required for piping plover population stability along the Atlantic Coast. They also noted that regional trends within the metapopulation over a 5 -year period did not follow predictions of the model and that actual mean fecundity required to maintain the population size might be lower. Our results suggested that the metapopulation would persist at a mean reproductive rate of 1.25 fledged per pair per year, but that numbers of individuals ultimately would decrease substantially without slightly higher fecundity. Our models also indicated discrepancies in the accuracy of predicting trends at the metapopulation level compared to those of the component populations. Although the differences might reflect inaccuracies in census results or productivity estimates, the sensitivity analyses suggest that population-specific rates of survivorship and interpopulation movements need to be determined to improve accuracy of the models, particularly among component populations.

\subsection{Additional considerations}

We did not consider possible effects of population density on any of the demographic parameters in our models. High densities may be predicted to result in reduced fecundity, increased emigration, or higher mortality; however, few data exist to demonstrate any general pattern of effect. Prindiville-Gaines and Ryan (1988) observed a reduction in mean reproductive success with a doubling of numbers of breeding pairs, while Mayer (1991) later found that reproductive success within the same alkali lake wetland system was negatively correlated with piping plover nesting density, as predation rates of eggs and chicks were significantly higher at beaches with higher plover densities. It is unclear, however, whether similar relationships are likely to be found within other breeding habitat types and to what degree density and environmental factors covary. 
Very low population densities may also result in reduced reproductive success through behavioral mechanisms (Allee effect) or genetic consequences (inbreeding depression). Reproductive rates were particularly low at the smallest populations and subpopulations in our models (in Colorado and at Lake of the Woods, MN); however the causal nature of this correlation cannot be discerned. Furthermore, $51 \%$ of birds observed during the 1996 International Piping Plover Breeding Census were found at sites containing fewer than ten breeding pairs, and $9.2 \%$ were at sites with only a single pair present (Plissner and Haig, 1997). This suggests that a large proportion of the population breeds in areas with low local densities. In general, piping plover productivity monitoring has focused upon study areas with higher breeding densities; however, Schwalbach (1988) reported highest fledging success along Missouri River reaches where mean "colony" size was a single pair.

Catastrophic events that periodically have severe negative effects on survival and/or reproduction may also potentially reduce persistence probabilities of populations and metapopulations. We chose not to incorporate catastrophes in our models, primarily because mean demographic values and variances were derived during time periods that include years of extreme fluctuations in environmental conditions, particularly in the Great Plains.

We also did not address factors that may decrease viability through reductions in genetic fitness. Throughout most of the species' range, inbreeding depression and other deleterious gene combinations associated with a loss of heterozygosity are unlikely to seriously threaten current populations. However, smaller and rapidly declining populations such as the Great Lakes, Colorado, Manitoba, and Lake of the Woods birds may be particularly susceptible to genetic load, especially if rates of dispersal between populations are also low or declining.

We found converse influences of dispersal rates on viability of Atlantic coast and Great Lakes/Great Plains metapopulations and component populations. In part, this result stems from contrasting rates of dispersal among the two largest and most productive populations in each metapopulation. In our models, all populations have equivalent dispersal rates with all neighboring populations. In actuality, these rates of exchange are likely to be more disparate.

\subsection{Implications for piping plover recovery}

The relatively promising outlook for Atlantic Coast birds results directly from intensive management of the breeding population throughout its coastal breeding range since 1985. Specifically nest protection efforts have significantly increased reproductive rates at existing breeding sites (US Fish and Wildlife Service, 1996). Continued viability depends in large part upon a continuation of such efforts, as fecundity would otherwise likely drop below levels required for persistence. Alternatively, results of our models indicate that extensive new efforts are necessary to produce a viable population of piping plovers in the Great Plains and Great Lakes. Although the metapopulation is likely to persist for another century if mean reproductive rates increase by $36 \%$ in the near future, the resulting population is still predicted to decline substantially in size and distribution. Obtaining mean productivity rates needed to stabilize or even increase the population size appears to be beyond the reach of the most ambitious management plans.

While reproductive rates are apparently the most directly-manageable of factors influencing extinction risk, alternatives need to be explored. Information on mortality patterns in the species is generally lacking. If survivorship rates are actually higher than the estimates used in the baseline models, lower fecundity will be sufficient to meet viability goals. In addition, determination of temporal or geographic patterns of mortality may enable modification of persistence probabilities by targeting measures that directly increase survivorship.

Because of concerns about injuries associated with leg bands, there are currently very few efforts to mark individual piping plovers in wild populations, despite intensive monitoring programs throughout the breeding range. Although reproductive rates are generally wellknown for most populations, demographic information relating to survivorship and dispersal is currently inadequate for most populations. Current work on genetic diversity of piping plover populations (by the second author), may reveal historic patterns of gene flow, from which dispersal rates may be inferred; but because of recent changes in the species distribution, notably the demise of an extensive Great Lakes population, the relevance of such patterns to current rates of interpopulation movements is questionable. Thus, resightings of individually marked birds still provide the best means for assessing these parameters.

\subsection{Utility of models}

Population viability models do not serve as predictors of minimum viable population sizes (Possingham et al., 1993; Caughley, 1994), but rather they are useful as tools providing probabilities of relative success for developing and assessing alternative population management strategies (National Research Council, 1995; Lindenmayer and Possingham, 1996). In the absence of complete data for input parameters, model sensitivity should be addressed for a realistic range of values of the inexact parameters. Nevertheless, without initial estimates of multiple model parameters, the usefulness of 
sensitivity analyses is limited, as multiple interaction effects and synergistic contributions of risk factors are possible. The models therefore only provide a minimum estimate of risk, associated with deviation from input parameter values (National Research Council, 1995).

Of additional consideration in using such models to develop conservation strategies is the time period for which persistence is defined. Population viability is loosely defined in terms of persistence probabilities over a fixed number of years, frequently a century or more. For species such as piping plovers, whose principal habitats are subject to high potential and actual human disturbance, attempts to simulate population growth trajectories over long time periods are particularly problematic, given the uncertaintities of future environmental policy and human pressures on demographic processes as well as on habitat availability and suitability.

Faced with the necessity to establish concrete recovery objectives with incomplete population data, PVA, and specifically mPVA, nonetheless offer valuable perspectives of recovery goals and processes for attaining them. With piping plovers, these models demonstrate the need to avoid generalizing dynamics of multiple populations of a species and to carefully consider designation of recovery units. Individual population demographics need to be determined and the connectivity among populations considered carefully in setting appropriate goals.

\section{Acknowledgements}

Anne Hecht (US Fish and Wildlife Service) provided much of the recent fecundity data for Atlantic Coast populations and offered many helpful comments regarding Atlantic populations for a preliminary report on these models. Most of the demographic data used for the baseline models was derived from the unpublished work of the following: D. Amirault, S. Boates, J. Brazil, R. Chiasson, J. Corbett, R. Cross, R. Etcheberry, S. Flemming, L. Gelvin-Innvaer, A. Hecht, R. Jenkins, J. Jones, J. Kumer, P. Laporte, C. Liebelt, D. McAskill, S. Melvin, J. Nicholls, C. Raithel, K. Terwilliger, J. Victoria, L. Wemmer, F. Cuthbert, M. Feirer, L. Heyens, S. Maxson, R. Jones, W. Koonz, P. Goossen, C. Grondahl, L. Hanebury, W. Harris, D. Hjertaas, K. Johnson, C. Kruse, D. McAdam, N. McPhillips, S. Smith, E. Wiltse, J. Dinan, S. Howell, J. Sidle, M. Carter, R. Estelle, and D. Nelson. We also thank Steve Garman for helpful discussions throughout the course of this work. This study was funded by the National Biological Service Species at Risk Program and the IUCN Conservation Breeding Specialist Group. Additional support was provided by the USGS Forest and Rangeland Ecosystem Science Center and by Lewis Oring at the University of Nevada-Reno. We also thank the hundreds of biologists in the United States and Canada that annually contribute to the collection of piping plover demographic data and formally and informally provided information to recovery team leaders.

\section{References}

Boyce, M.S., 1992. Population viability analysis. Annual Review of Ecology and Systematics 23, 481-506.

Burgman, M.A., Ferson, S., Akcakaya, H.R., 1993. Risk assessment in conservation biology. Chapman and Hall, London.

Canadian Wildlife Service, 1989. Canadian piping plover recovery plan. Ontario, Canada.

Caughley, G., 1994. Directions in conservation biology. Journal of Animal Ecology 63, 215-244.

Gilpin, M.E., Soulé, M.E., 1986. Minimum viable populations: processes of species extinction. In: Soulé, M.E. (Ed.), Conservation Biology: The Science of Scarcity and Diversity. Sinauer Associates, Sunderland, MA, pp. 13-34.

Haig, S.M., 1985. The status of the piping plover in Canada. Report prepared for the Committee on the Status of Endangered Wildlife in Canada. National Museum of Canada, Ottawa.

Haig, S.M., 1992. Piping plover. In: Poole, A., Stettenheim, P., Gill, F. (Eds.), The Birds of North America, No. 2. The Academy of Natural Sciences, Philadelphia, PA/The American Ornithologists' Union, Washington, DC, pp. 1-18.

Haig, S.M., Oring, L.W., 1988a. Distribution and dispersal in the piping plover. Auk 105, 630-638.

Haig, S.M., Oring, L.W., 1988b. Genetic differentiation of piping plovers across North America. Auk 105, 260-267.

Haig, S.M., Plissner, J.H., 1993. Distribution and abundance of piping plovers: results and implications of the 1991 International Census. Condor 95, 145-156.

Harcourt, A.H., 1995. Population viability estimates: theory and practice for a wild gorilla population. Conservation Biology 9, 134-142.

Lacy, R.C., 1993. VORTEX: a computer simulation model for population viability analysis. Wildlife Research 20, 45-65.

Lacy, R.C., Hughes, K.A., Miller, P.S., 1995. VORTEX: a stochastic simulation of the extinction process. Version 7. IUCN/SSC Conservation Breeding Specialist Group, Apple Valley, Minnesota.

Lesica, P., Allendorf, F.W., 1995. When are peripheral populations valuable for conservation? Conservation Biology 9, 753-760.

Lindenmayer, D.B., Possingham, H.P., 1996. Applications of population viability analysis in conservation biology in Australia. In: Settele, J., Margules, C.R., Poschlod, P., Henle, K. (Eds.), Species Survival in Fragmented Landscapes. Kluwer Academic. Dordrecht, The Netherlands, pp. 102-110.

Loegering, J.P., 1992. Piping plover breeding biology, foraging ecology and behavior on Assateague Island National Seashore, Maryland. M.S. thesis, Virginia Polytechnic Institute and State University, Blacksburg, VA.

Lomolino, M.V., Channell, R., 1995. Splendid isolation: patterns of geographic range collapse in endangered mammals. Journal of Mammalogy 76, 335-347.

MacIvor, L.H., 1990. Population dynamics, breeding ecology, and management of piping plovers on outer Cape Cod, Massachusetts. M.S. thesis. University of Massachusetts, MA.

Mayer, P.M., 1991. Conservation biology of piping plovers in the Northern Great Plains. M.S. thesis, University of Missouri, MO.

McCullough, D.R., 1996. Introduction. In: McCullough, D.R. (Ed.), Metapopulations and Wildlife. Island Press, Washington, DC, pp. $1-10$.

Melvin, S.M., Gibbs, J.P., 1994. Viability analysis for the Atlantic Coast population of piping plovers. Report to the US Fish and Wildlife Service, Sudbury, MA. 
National Research Council., 1995. Science and the Endangered Species Act, National Academy Press, Washington, DC.

Plissner, J.H., Haig, S.M., 1997. 1996 International Piping Plover Census. US Geological Survey, Biological Resources Division report.

Plissner, J.H., Haig, S.M. Strategies for monitoring status of a broadly-distributed endangered species: results and implications of the second international piping plover census. Canadian Journal of Zoology, submitted for publication.

Possingham, H.P., Lindenmayer, D.B., Norton, T.W., 1993. A framework for improved threatened species management using population viability analysis. Pacific Conservation Biology 1, 39-45.

Prindiville-Gaines, E., Ryan, M.R., 1988. Piping plover habitat use and reproductive success in North Dakota, USA. Journal of Wildlife Management 52, 266-273.

Root, B.G., Ryan, M.R., Mayer, P.M., 1992. Piping plover survival rate in the Great Plains. Journal of Field Ornithology 63, 10 15.

Ryan, M.R., Root, B.G., Mayer, P.M., 1993. Status of piping plovers in the Great Plains of North America: a demographic simulation model. Conservation Biology 7, 581-585.

Schwalbach, M.J. 1988. Conservation of least terns and piping plovers along the Missouri River and its major tributaries in South Dakota. M.S. thesis, University of South Dakota, Vermillion, 5D.

Tear, T.H., Scott, J.M., Hayward, P.H., Griffith, B., 1993. Status and prospects for success of the Endangered Species Act: a look at recovery plans. Science $262,976-977$.

US Fish and Wildlife Service, 1985. Endangered and threatened wildlife and plants; Determination of endangered and threatened status for the piping plover - Final rule. Federal Register 50 (238), 5072650734.

US Fish and Wildlife Service, 1988a. Atlantic Coast piping plover recovery plan. US Fish and Wildlife Service, Newton Corner, MA.

US Fish and Wildlife Service, 1988b. Recovery plan for piping plovers breeding on the Great Lakes and Northern Great Plains. US Fish and Wildlife Service, Twin Cities, MN.

US Fish and Wildlife Service, 1996. Piping Plover (Charadrius melodus) Atlantic Coast population revised recovery plan, US Fish and Wildlife Service, Hadley, MA.

Wilcox, L.R., 1959. A twenty year study of the piping plover. Auk 76, 129-152.

Wu, J., Vankat, J.L., Barlas, Y., 1993. Effects of patch connectivity and arrangement on animal metapopulation dynamic: a simulation study. Ecological Modeling 65, 221-254. 